\title{
ANALISIS IMPLEMENTASI ASESMEN DALAM MENGAMATI PERKEMBANGAN ANAK TUNAGRAHITA DI TK SLB C 1 DHARMA RENA RING PUTRA I YOGYAKARTA
}

\author{
Muhammad Zainal Abidin \\ PIAUD Universitas Islam Sunan Kalijaga Yogyakarta \\ Email : Zabid27@gmail.com
}

\begin{abstract}
Abstrak
Tujuan penelitian ini yaitu unutk menganalisis proses implementasi asesmen yang diterapkan untuk anak tunagrahita, menemukan pola perkembangan anak tunagrahita, serta mencari problematika pelaksanaan asesmen di TK LB C1 Dharma Rena Ring Putra. Penelitian ini merupakan penelitian kualitatif dengan metode pengumpulan data observasi, wawancara, dan dokumentasi. Analisis data dilakukan dengan langkah mereduksi data, menyajikan data serta menyimpulkan data. Pemerikasan keabsahan data dilakukan dengan menggunakan triangulasi teknik. Hasil penelitian menunjukan proses pelaksanaan asesmen di TK LB C 1 Drama Rena Ringputra I Yogyakarta dialkukan dengan dua cara yaitu: Pertama, Asesmen perkembangan anak disabilitas, pelaksanan dimulai dengan asesmen prasekolah yang bertujuan untuk mendiskripsikan kemampuan serta hambatan pada anak sebelum masuk sekolah, kemudia dilanjutkan asemen pasca sekolah, sebagai tindak lanjut sesmen pasca sekolah yang bertujuan mengembangkan kemampuan anak dengan mengacu tahapan perkembangan anak disabilitas atau TPPAD (Tingkat Pencapaian Perkembangan Anak Disabilitas). Kedua, Asesmen perkembangan anak tunagrahita dari sudut kenormal, pelaksanan asesmen anak disabilitas dari kenormal dimulai dengan pengamatan setiap hari, pencatatan harian, menganalisa data setiap bulan dan rekap perkembangan selama semester dengan mengacu pada STPPA (Setandar tingkat pencapaian perkembangan anak). Pola perkembangan anak tunagrahrita selalu berkembang berpasang-pasangan, aspek kognitif selalu berpasangan dengan aspek motorik, aspek sosial emosional berpasangan dengan nilai moral agama sedangakan aspek perkembangan bahasa dan seni selalu mengiringi aspek-aspek tersebut. Problem matika pelaksanaan asesmen, masih kurang pahamnya akan pelaksanaan asesmen, kurangnya buku panduan asesmen.
\end{abstract}

Kata Kunci: Tunagrahita, Asesmen, Perkembangan anak.

\begin{abstract}
The purpose of this study is to analyze the assessment implementation process applied to mentally retarded children, find patterns of development of mentally retarded children, and look for problems in carrying out assessments at TK LB C1 Dharma Rena Ring Putra. This research is a qualitative research with location in SLB C-1 Dharma Rena Ring Putra I Yogyakarta. Data collection is done by observation, interview, and documentation. Data analysis is done by reducing, presenting and concluding data. Data validity is done by using technique triangulation. The results showed the process of conducting the assessment in TK LB C 1 Drama Rena Ringputra I Yogyakarta was conducted in two ways: disabled child development assessment, the implementation begins with a preschool assessment that aims to describe the ability and barriers to the children before entering school, then continued assessment of post-school, as a follow-up post-school assessment that aims to develop and maximize the ability of children by referring to the development stage of children with disability or commonly called TPPAD (Level Achievement of Children Development Disability). Second, the assessment of the development of the intellectual disability children from the normal point, the implementation of the child's assessment of disability from the normality begins with daily observation, daily recording, analyzing data every month and recap the progress during the semester. The process of implementing the child's assessment of intellectual disability from the angle of normality refers to STPPA (Standard level of child development achievement).. Pattern development of intellectual disability children always develop in pairs, cognitive aspect always pairs with motor aspect, emotional social aspect paired with religion moral value while the aspect of language development and art always accompany those aspects.
\end{abstract}


Problematic implementation of the assessment is the absence of assessment standards and appraisal books for intellectual disability children.

Keyword : mentally disabled, assessment, childrent development

\section{PENDAHULUAN}

Mendidik merupakan usaha yang harus dilakukan oleh keluarga, masyarakat, dan pemerintah melalui kegiatan bimbingan, pembelajaran, dan latihan yang berlangsung di mana pun dan kapan pun untuk mempersiapkan peserta didik dalam menjalankan perannya di dalam masyarakat.. Di dalam pustaka lain, pendidikan adalah semua perbuatan atau usaha dari generasi tua untuk mentrasfer pengetahuan, pengalaman, kecakapan, ketrampilan, kepada generasi muda, sebagai usaha untuk menyiapkan mereka agar dapat memenuhi fungsi hidupnya, baik jasmani maupun rohani (zuhairini, 1992:92).

Pendidikan anak usia dini adalah tahapan terpenting dalam menentukan anak (Setiawan, 2014).

Kualitas pembelajaran salah satunya ditentukan dari kualitas asesmen yang dilakukan oleh guru dalam proses pembelajaran. Kegiatan asesmen dapat membantu guru memahami kekuatan dan kelemahan yang dialami oleh siswa dalam proses pembelajaran. Semakin berkualitas asesmen di dalam proses pembelajaran, pemahaman guru akan kelemahan dan kekuatan siswa dalam mempelajari materi tertentu semakin baik. Dengan melaksanakan asesmen yang berkualitas guru dapat memiliki acuan untuk mengambil keputusan yang efektif dalam proses pembelajaran anak usia dini. Asesmen juga dapat memberikan informasi pada siswa tentang kemajuan belajarnya aspek perkembangan anak. Masa keemasan the golden ages merupakan tahapan dominasi perkembangan anak dimana $80 \%$ aspek kemampuan seseorang anak berkembang pesat. Pendidikan pada usia dini pada dasanya meliputi seluruh upaya dan tindakan yang dilakukan oleh pendidik dan orangtua dalam proses perawatan, pengasuhan, dan pendidikan anak. Anak usia dini menjadi center of behavior science atau dapat diartikan sebagai tahapan perkembangan otak manusia. Ciri the golden ages tetap melekat pada paradigma yang menjadikan pembentukan sikap anak di masa depan. Sehingga dengan demikian keberhasilan sebuah pembelajaran secara tidak langsung menentukan masa depan

sehingga siswa dapat memperbaiki perilaku belajarnya.

Pentingnya peranan asesmen dalam pembelajaran telah ditekankan secara eksplisit dalam Peraturan Menteri Pendidikan Dan Kebudayaan nomor 23 tahun 2016 tentang Standar Penilaian Pendidikan. Peraturan tersebut menjelaskan bahwa penilaian dilakukan untuk memantau dan mengevaluasi proses, kemajuan belajar, dan perbaikan hasil belajar peserta didik secara berkesinambungan. Beberapa langkah kegiatan penilaian diantaranya adalah sebagai berikut: (1) perancangan strategi penilaian oleh pendidik dilakukan pada saat penyusunan rencana pelaksanaan pembelajaran (RPP) berdasarkan silabus; (2) penilaian aspek sikap dilakukan melalui 
observasi/pengamatan dan teknik penilaian lain yang relevan, dan pelaporannya menjadi tanggungjawab wali kelas atau guru kelas; (3) penilaian aspek pengetahuan dilakukan melalui tes tertulis, tes lisan, dan penugasan sesuai dengan kompetensi yang dinilai; (4) penilaian keterampilan dilakukan melalui praktik, produk, proyek, portofolio, dan/atau teknik lain sesuai dengan kompetensi yang dinilai; (5) hasil penilaian pencapaian pengetahuan dan keterampilan peserta didik dapat disampaikan dalam bentuk angka maupun deskripsi .

Asesmen adalah kegiatan pengumpulan informasi dalam rangka pengambilan keputusan. Dalam konteks pembelajaran, asesmen berarti pengumpulan berbagai informasi terkait proses dan hasil belajar anak yang digunakan untuk menentukan pengambilan keputusan yang perlu dilakukan dalam proses pembelajaran (Rasyid, 2012:11). Jika asesmen tidak dilakukan secara tepat dan akurat informai yang akan dihasilkan tidak akan sesuai dengan keadaan yang terjadi pada anak, bahkan akan berdampak buruk bagi perkembangan anak karena kesalahan guru dalam mengambil tindakan. Oleh sebab itu perlu adanya konsep asesmen yang mampu mengambarkan perkembangan anak.

Pada dasarnya asesmen dapat dilakukan dengan mudah ketika membaca dan memahami langkah-langkah dalam melakukan asesmen, terlebih jika asesmen dilakukan pada anak-anak normal, namun bagaimana jika penilaian dilakukan pada anak berkebutuhan khusus tidak mesti semua guru mau dan mampu melakukan penilaian pada anak berkebutuhan khusus. Sedangkan pada kenyataanya asesmen dalam arti penilaian yang saat ini mengacu pada permendikbud 137 tahun 2014 dan permendikbud 146 tahun 2014 belum sepenuhnya sesuai untuk diterapkan pada anak berkebutuhan khusus. Pada dasarnya anak berkebutuhan khusus memiliki tingkatan perkembangan kemampuan serta kebiasaan yang berbeda pada anak normal. Jika kita mampu mengetahu apa yang dibutuhkan anak maka kita akan lebih siap dan berani dalam bertindak di kelas dalam menghadapi anak ABK.

Salah satu lembaga pendidikan ABK yang bernama TK LB C1 Dharma Rena Ringputra I Yogyakarta, merupakan lembaga pendidikan yang mengajar dan mendidik anak tunagrahita tunagrahita baik yang berada pada level ringan, sedang maupun berat yang juga memiliki kelainan CP (cerebral palsy). Cerebral Palsy merupakan kelainan yang berasal dari tidak berfungsinya otot dan urat syaraf (neoromuscular disorder) yang disebabkan gangguan pada otak, urat syaraf, panca indera (sensory disorder), ingatan (menta disorder), perasaan dan jiwa (psichologia disorder) (Tifali, 2011).

Dari uraian di atas maka peneliti tertarik untuk meneliti bagaimana proses implementasi asesmen yang diterapkan untuk anak tunagrahita, menemukan pola perkembangan anak tunagrahita, serta mencari problematika pelaksanaan asesmen di TK LB C1 Dharma Rena Ring Putra. 


\section{METODE PENELITIAN}

Penelitian ini menggunakan pendekatan kualitatif dengan objek yang terdiri dari guru dan peserta didik. Pemilihan objek atau responden ditentukan dengan teknik purposive sampling yaitu teknik memilih narasumber atau objek penelitian dengan beberapa pertimbangan dan tujuan tertentu. Objek penelitian haruslah orang yang mengetahui, memahami, dan mengalami kejadian atau situasi sosial yang akan diteliti. Hal ini dilakukan agar data yang didapat sesuai dengan tujuan peneliti pada awal penelitian (Sugiyono, 2008 :298).

Adapun pengumpulan data dalam penelitian ini menggunakan beberapa teknik dan metode, antara lain metode observasi, metode interview, dan teknik dokumentasi,. Data-data yang didapatkan dianalisis menggunakan teknik trianggulasi. Penggunaan teknik triangulasi bertujuan untuk mengumpulkan data sekaligus menguji kredibilitas data, atau mengecek data dengan berbagai teknik pengumpulan data dan berbagai sumber data. Triangulasi yang digunakan adalah triangulasi teknik, dimana menggunakan teknik pengumpulan data yang berbeda-beda untuk mendapatkan data dari sumber yang sama.

Analisis data kualitatif bersifat induktif, hal ini dikarenakan berdasarkan data yang diperoleh, selanjutnya dikembangakan pola hubungan tertentu sehinga menjadi sebuah kesimpulan sementara. Langkah-langkah yang dapat dilakukan dalam menganalisis data kualitatif adalah sebagai berikut: (1) Menelaah data yang telah didapatkan dari hasil wawancara, observasi, dan dokumentasi; (2) Melakukan reduksi data, yaitu menentukan dan memilih data yang sekiranya dapat dianalisis lebih lanjut; (3) Menyusun seluruh data yang telah didapat sesuai dengan urutan pembahasan yang telah direncanakan; dan (4) Memeriksa keabsahan data, dilanjutkan dengan tahap penafsiran data kemudian mengelola hasil data dalam bentuk narasi sesuai dengan telaah pustaka dari hasil teori yang digunakan(Moleong, 2007:247).

\section{HASIL DAN PEMBAHASAN}

\section{A. Implementasi Asesmen}

Asesmen adalah kegiatan pengumpulan informasi dalam rangka pengambilan keputusan yang berdasarkan informasi yang telah didapat. Dalam konteks pembelajaran, asesmen berarti pengumpulan berbagai informasi tentang proses dan hasil belajar siswa dalam rangka menentukan keputusan-keputusan yang perlu dilakukan dalam pembelajaran. Beberapa karakteristik asesmen dalam pembelajaran dibagi menjadi beberapa jenis, antara lain: (1) Asesmen dimulai dengan pengumpulan berbagai informasi tentang siswa dalam pembelajaran; (2) Dalam kegiatan asesmen dilakukan analisis dan interpretasi terhadap data dan informasi yang berhasil dikumpulkan; (3) Interpretasi menghasilkan keputusan-keputusan tentang pembelajaran; (4) Terdapat tindak lanjut terhadap keputusan yang dihasilkan; dan (5) Asesmen dilakukan secara berkelanjutan (Kusairi, 2012). 
Muhammad Zainal Abidin. ANALISIS IMPLEMENTASI ASESMEN DALAM MENGAMATI PERKEMBANGAN ANAK TUNAGRAHITA DI TK SLB C 1 DHARMA RENA RING PUTRA I YOGYAKARTA. Early Childhood Vol. 2 No. 2a, November 2018

Asesmen tidak digunakan untuk mengukur keberhasilan suatu program, tetapi untuk mengetahui perkembangan atau kemajuan belajar anak. Harun rasyid dalam bukunya asesmen perkembangan anak usia dini menjelaskan bahwa asesmen bagi anak usia dini dan taman kanak-kanak bukan bertujuan untuk mengukur prestasi dan mencapai keberhasilan skolastik, melainkan untuk melihat tingkat kemajuan perkembangan serta kemampuan yang telah dilakukan anak dalam berbagai tindakan, sikap, kinerja, dan tampilan mereka.

Prinsip asesmen bagi anak usia dini dan taman kanak-kanak adalah proses memahami tingkat perkembangan dan pertumbuhan kemampuan anak secra terus menerus dengan cara mengumpulkan data melalui pengamatan, pencatatan, rekaman, terhadap perilaku yang ditampilkan (Rasyid, 2012:142). Asesmen tidak dilakukan di kelas pada akhir program atau di akhir tahun, tetapi dilakukan secara bertahap dan berksesinambungan sehingga kemajuan belajar siswa dapat diketahui. Seperti: ketika anak bermain, menggambar atau dari karya yang dihasilkan. Asesmen tidak mengkondisikan anak pada bentuk ujian.

Pelaksanaan asesmen yang dilakukan guru dalam mengamati perkembangan anak di TK LB C 1 Drama Rena Ringputra I Yogyakarta dilakukan dengan dua cara diantaranya (1) Asesmen Perkembangan anak dari kecacatan atau kedisabilitasannya, (2) Asesmen untuk mengamati perkembangan anak tunagrahita dari sudut kenormalanya.

\section{Asesmen Perkembangan Anak Disabilitas}

a. Tahapan Pelaksanaan Asesmen Anak Disabiltas

Pelaksanaan asesmen untuk mengamati perkembangan dari kedisabilitasanya dilakukan untuk mengamati kemampuan serta perkembangan anak terutama dalam menjalani kehidupanya sehari-hari pelaksanaa asesmen dimulai sebelum anak masuk sekolah atau prasekolah. Adapun langkah-langkah pelaksanaan asesmen perkembangan anak disabilitas sebagai berikut:

1) Asesmen Prasekolah Asesmen prasekolah dilakukan suatu usaha seseorang guru untuk mengetahui apakah seorang anak mengalami kelainan atau penyimpangan (phisik, intelektual, social, emosional/tingkah laku) dalam pertumbuhan dan perkembangannya dibandingkan dengan anak-anak lain seusianya (anak-anak normal) atau sebagai roses pendektesia dini terhadap anak berkebutuhan khusus. Asesmen prasekolah yang dilakukan ketika anak belum masuk dilakukan dengan mengunakan protol.

Protokol merupakan sebuah data yang berisikan mengenai latar belakang anak baik situasi keluarga, situasi lingkungan, situasi kepribadian, analisis kemampuan serta ketidak 
mampuan, permasalahan yang pernah dialami, dan analisis kebutuhan yang diperlukan anak. Pada dasarnya protokol atau bisa dikatakan sebagai asesmen informal bersifat rahasia maka nama dan data-data yang terdapat di atas sudah disamarkan supaya tidak ada kerugian bagi lembaga yang terkait. Setelah dilakukan pengidentivikasi prasekolah kemudian guru akan membuat PPI (program pengembangan individu) yang disesuaikan pada tingkatan perkembangan anak disabilitas.

2) Asesemen perkembangan anak paca sekolah

Asesmen perkembangan anak pasca sekolah dilakukan setelah anak masuk sekolah tepatnya dilakukan setelah pembuatan program pengembangan individu. Pelaksanaan asesmen perkembangan anak disabilitas berbeda dengan asesmen perkembangan anak normal. Jika asesmen perkembangan anak normal pada pelaksanaannya mengacu pada permendikbud no 146 tahun 2013 dan no 137 tahun 2014 tentang standar tingkat pencapaian perkembangan anak. Sedangkan asesmen untuk anak disabilitas dalam mengamati perkembangan anak dari aspek kecacatannya menggunakan tahapan perkembangan sendiri atau biasa yang disebut dengan TPPAD (Tingkat Pencapaian Perkembangan Anak Disabilitas). Pembuatan TPPAD dilakukan untuk memudahkan guru dalam melakukan asesmen serta menentukan sejauh mana kemampuan dan perkembangan anak, menentukan rancangan pembelajaran yang sesuai dengan tingkat perkembangan anak, meskipun dapat dasarnya TPPAD mengacu pada standar tingkat pencapaian anak pada umumnya (STPPA).

Lingkup tingkat pencapaian perkembangan anak disabilitas, dengan mengamati perkembangan dari kemandirianya diantaranya: bantudiri, komunikasi, sosial dan pekerjaan. Lingkup perkembangannya lebih sederhana dibandingkan lingkup perkembangan anak normal. Pada sekolahan TK LB C Drama Rena Ringputra I Yogyakarta tingkat pencapaian perkembangan tersebut dijadikan sebuah landasan dalam membuat asesmen, berikut bentuk asesmen yang dikembangkan dari TPPD.

Asesmen Anak Disabilitas
$\begin{aligned} & \text { Nama } \quad: \\ & \text { Usia } \quad 1 \text { tahun } \\ & \text { A. Petunjuk } \\ & \text { Berikan tanda (+) bila anak bisa melakukan } \\ & \text { Berikan tanda (-) bila anak tidak bisa } \\ & \text { melakukan } \\ & \text { Berikan tanda kosong bila tidak dapat diakses } \\ & \text { (tidak dikerjakan sama dan sebagainya) }\end{aligned}$


Muhammad Zainal Abidin. ANALISIS IMPLEMENTASI ASESMEN DALAM MENGAMATI PERKEMBANGAN ANAK TUNAGRAHITA DI TK SLB C 1 DHARMA RENA RING PUTRA I YOGYAKARTA. Early Childhood Vol. 2 No. 2a, November 2018

\section{HA : Hasil Asesmen \\ No : Nomor item}

\section{B. Instrumen Asesmen}

Tabel 2. Asesmen Anak Disabilitas Bentuk Ceklis

\begin{tabular}{|c|c|c|}
\hline No & Pekembangan yang diamati & HA \\
\hline \multirow[t]{4}{*}{1} & Bantu diri (Kebiasaan waktu makan ) & \\
\hline & $\begin{array}{l}\text { a. dapat menggunakan sendok tanpa } \\
\text { bantuan }\end{array}$ & \\
\hline & $\begin{array}{l}\text { b. memegang dan mengangkat gelas } \\
\text { tanpa bantuan }\end{array}$ & \\
\hline & a. Dapat mengambil minum sendiri & \\
\hline \multirow[t]{4}{*}{2} & Bantu diri (Mobilitas ) & \\
\hline & $\begin{array}{l}\text { a. naik tangga dengan dua kaki } \\
\text { bersama pada masing masing anak } \\
\text { tangga }\end{array}$ & \\
\hline & $\begin{array}{l}\text { b. turun tanggan dengan kedua kaki } \\
\text { bersama pada masing masing anak } \\
\text { tangga }\end{array}$ & \\
\hline & $\begin{array}{l}\text { C. dapat bermain dengan permainan } \\
\text { kendaraan }\end{array}$ & \\
\hline \multirow[t]{3}{*}{3} & Komunikasi (Bahasa) & \\
\hline & $\begin{array}{l}\text { a. dapat mengikuti perintah perintah } \\
\text { sederhana }\end{array}$ & \\
\hline & $\begin{array}{l}\text { b. mengerti kata depan belakang, di } \\
\text { dalam, ke bawah, di bawah }\end{array}$ & \\
\hline \multirow[t]{3}{*}{4} & Komunikasi (Perbedaan) & \\
\hline & $\begin{array}{l}\text { a. dapat membedakan dengan benar } \\
\text { antara satu dan banyak }\end{array}$ & \\
\hline & $\begin{array}{l}\text { b. dapat membedakan jenis kelamin, } \\
\text { pria, wanita, anak laki-laki, dan } \\
\text { anak perempuan }\end{array}$ & \\
\hline \multirow[t]{3}{*}{5} & sosialisasi (aktivitas bermain) & \\
\hline & a. dapat bermain bersama kelompok & \\
\hline & $\begin{array}{l}\text { b. menunggu giliran dalam permainan } \\
\text { atau membagi mainan dengan teman }\end{array}$ & \\
\hline \multirow[t]{3}{*}{6} & Sosialisasi (aktivitas di rumah) & \\
\hline & $\begin{array}{l}\text { a. dapat mengambil dan membawa } \\
\text { sesuatu menurut perintah }\end{array}$ & \\
\hline & $\begin{array}{l}\text { b. membantu pekerjaan rumah (tugas- } \\
\text { tugas) rumah tangga }\end{array}$ & \\
\hline 7 & pekerjaan (keterampilan) & \\
\hline
\end{tabular}

\begin{tabular}{|c|l|l|} 
& $\begin{array}{l}\text { a. dapat merangkai manik-manik yang } \\
\text { besar }\end{array}$ & \\
\hline & b. dapat membuka tutup yang di putar & \\
\hline 8 & Pekerjaan(ketangkasan) & \\
\hline & a. dapat menendang bola tanpa jatuh & \\
\hline & b. dapat memukul bola dengan alat & \\
\hline
\end{tabular}
Asesmen yang ada di atas merupakan pengembangan asesmen dalam bentuk ceklis yang dikembangkan dari tingkat pencapaian anak disabilitas. Adapun cara penggunaan format penilaian tersebut dengan menggunakan tanda (+) jika anak sudah bisa melakukan namun jika belum bisa melakukan memberikan tanda (-). Penggunaan tanda (+) / (-) digunakan untuk mencari batas kemampuannya, dari batas kemampuan tersebut dibuatlah sebuah program individu atau biasa disebut dengan (PPI) Program Pengembangan Individu. Namun apabila anak tersebut masih tetap tidak bisa berkembang atau tidak mungkin untuk mencapai tahapan perkembangan (TM) maka akan digantikan dengan tahapan perkembangan yang lain sampai pada hasilnya perkembangan anak akan memiliki poin (+) semua.

\section{b. Asesmen Perkembangan Anak Tunagrahita Dari Kenormalannya}

Pelaksanaan asesmen dalam mengamati perkembangan anak sebagai anak normal, meliputi beberapa aspek yang diamati yaitu: nilai agama dan moral, fisik motorik, kognitif, sosial emosional, bahasa dan seni. Dari aspek yang diamati pada dasarnya mekanisme dan pelaksanaan asesmen mengacu pada standar PAUD yakni permendikbud nomor 137/2014 dan permendikbud nomor 146/2014. Setiap aspek yang diamati 
memiliki cara yang berbeda dalam melakukan asesmen.

a. Tahapan Pelaksanaan Asesmen Anak Disabiltas Dari Kenormalannya

Pada dasarnya r proses
pelaksanaan asesmen
secara sistematis yang
dilakukan
pengamatan setiap hari, pencatatan
harian, penganalisa data setiap bulan
dan rekap perkembangan selama
semester. Berikut tahapan asesmen
perkembangan anak disabilitas dari
sudut kenormalanya:

1) Penilaian Harian

Penilaian harian merupakan proses pengumpulan data dengan menggunakan instrumen format penilaian harian yang tercantum dalam RPPH, catatan anekdot, hasil karya, observasi atau pengamatan. Instrumen format penilaian harian dilakukan dari hasil pengamatan guru dari kegiatan anak bermain atau melakukan kegiatan rutin harian dari awal masuk sampai akhir pembelajaran di sekolah. Sedangkan untuk hasil karya anak didapat setelah anak melakukan kegiatan sebagai bentuk dokumentasi guru. Pelaksanaan penilaian harian menggunakan checklist (V) dengan menggunakan pencapaian perkembangan yang terdapat pada RPPH (Rencana Pelaksanaan Pembelajaran Harian). checklist (V) berisikan indikator perkembangan untuk mengukur tercapainya tujuan dan kopetensi yang ditetapkan dalam
RPPM (Rencana Pelaksanaan

Pembelajaran Mingguan).

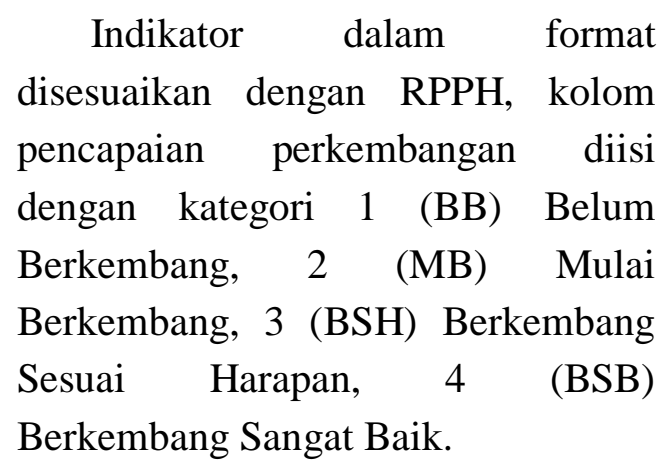

Beberapa teknik penilaian yang terdapat pada format penilaian harian disesuaikan dengan program pengembangan dan kebutuhan data apa yang diperlukan dari siswa. Berikut beberapa data dan teknik penilaian yang digunakan di SLB C 1 Drama Rena Ringputra.

a) Hasil Karya

Hasil karya merupakan buah pikir anak dalam bentuk karya nyata dari beberapa pekerjaan tangan, karya seni atau keterampilan anak, seperti: gambar, hasil mewarnai, lipatan, kolase, hasil guntingan, hasil coretan, hasil prakarya. Dari hasil karya anak juga adapat diamati perkembangan anak baik dari aspek perkembangan, kognitif, motorik, sosial emosional, moral agama, bahasa, serta seni. Hal ini dikarenakan setiap aspek perkembangan saling berkaitan dan terhubung, beriku contoh format penilaian hasil karya. 
Muhammad Zainal Abidin. ANALISIS IMPLEMENTASI ASESMEN DALAM MENGAMATI PERKEMBANGAN ANAK TUNAGRAHITA DI TK SLB C 1 DHARMA RENA RING PUTRA I YOGYAKARTA. Early Childhood Vol. 2 No. 2a, November 2018

\begin{tabular}{l} 
Contoh Format Penilaian Hasil \\
Karya \\
Tabel 3. Penilaian Bentuk Hasil Karya \\
Nama Anak : Aila \\
Dokumentasi : Hasil karya anak \\
\hline Hasil Karya Anak
\end{tabular}

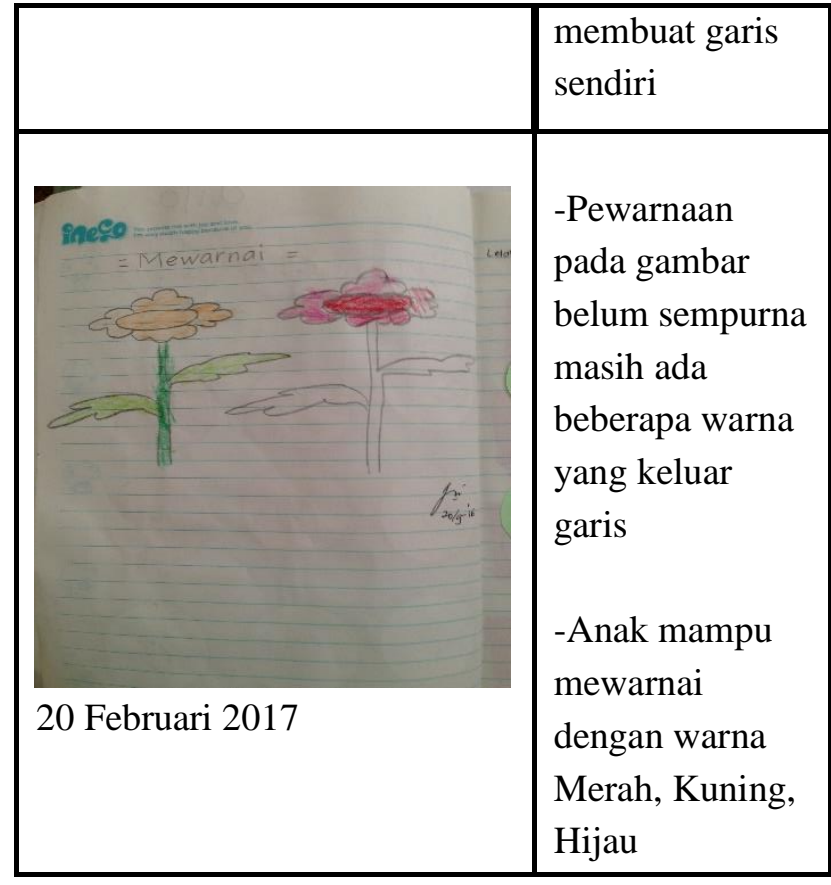

b. Catatan Anekdot

Catatan anekdot salah satu bagian penilaian teknik observasi, namun catatan anekdot digunakan untuk mencatat sikap dan perilaku anak yang muncul secara tiba-tiba atau peristiwa yang terjadi secara isindental. Hasil penelitian menunjukan catatan anekdot digunakan untuk mencatat seluruh fakta, yang menceritakan situasi yang dialami pada anak. Catatan anekdot dapat digunakan untuk mengetahui perkembangan anak yang indikatornya tercantum maupun tidak tercantum dalam RPPH.

c. Hasil Observasi

Observasi merupakan teknik penilaian yang digunakan dengan cara mencatat hasil pengamatan terhadap suatu objek tertentu. Pelaksanaan dengan teknik penilaian observasi dilakukan dari awal sampai akhir pembelajaran dan disesuaikan dengan jenis perkembangan yang diamati. 
Selain itu dalam pelaksanaannya dilakukan dengan mengunakan instrumen yang terdapat pada RPPH atau Penilaian Harian. Teknik penilaian dengan observasi biasa dilakukan untuk mengamati perkembangan sikap seperti sikap sosial emosional, dan moral agama anak. Dalam ranah sikap tersebut terdapat lima jenjang proses berfikir afektif yakni: (1) menerima atau memperhatikan, (2) merespon atau menanggapi, (3) menilai atau menanggapi, (4) mengorganisasi atau mengelola, dan (5) berkarakter.

2) Penilaian Bulanan dan Semester

Penialaian Bulanan sebuah tindak lanjut dari penilaian harian. Penilaian bulanan penekanannya lebih pada analisis dan interpretasi guru tehadap data yang terkumpul dari penilaian harian. Sumber data penilaian bulanan berasal dari penilaian harian baik berupa hasil karya, dan catatan anekdot. Pelaksanaan penilaian bulanan di TK LB C 1 Drama Rena Ringputra I dilakukan pada akhir semester atau 6 bulan hal ini dilakukan agar lebih mudah dalam melakukan pelaporan. Seperti yang disampaikan oleh Ibu Riatri Susanti dalam wawancara sebagai berikut:

"Untuk menindak lanjuti dari penilaian harian kita adakan penilaian bulanan dan biasanya saya lakukan pada akhir semester sebelum pembuatan laporan atau raport. Untuk pengisiannya yang saya masukan adalah pencapaian tertinggi yang paling tinggi dari hasilnya dia."
Berdasarkan pernyataan

tersebut, setelah melakukan penilaian harian dilakukan penilaian bulanan yang dilakukan sebelum pelaporan atau setiap akhir semester, hal ini dilakukan untuk merekap hasil dari penilaian harian. Dengan adanya penilaian berkelanjutan guru menjadi lebih mudah dalam menganalisis dan menginterpretasi hasil dari penilaian yang sudah didapat. Berikut bentuk penilaian bulanan yang di terapkan di TK LB C-1 Drama Rena Ringputra I Yogyakarta. Format penilaian bulanan.

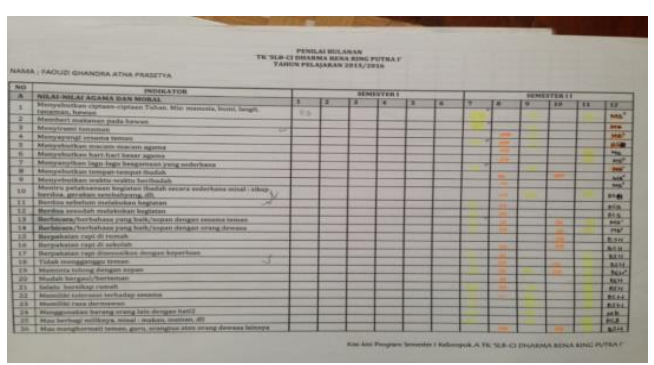

\section{B. Pola Perkembangan Anak \\ Tunagrahita di TK LB C1 Dharma Rena Ring Putra I Yogyakarta}

Perkembangan individu yang berlangsung sepanjang hayat, dimulai dari masa pertemuan sel ayah dan sel ibu dan berakhir pada kematian yang berlangsung berangsur-angsur sedikit demi sedikit. Setiap perkembangan individu anak memiliki bermacam-macam keunikan dan terkadang dipengaruhi berbagai macam faktor, baik dari dalam maupun dari luar. Perkembangan anak yang unik dan berbeda-beda antara satu dengan yang lain terkadang membuat kita kualahan untuk mengatasinya namun dengan mengunakan asesmen atau penilaian yang sistematis dan tersetruktur, kita akan tahu bagaimana pola 
perkembangan anak serta tahu bagaimana cara untuk mengatasi masalah pada anak. Berikut ini merupakan grafik hasil asesmen dari tiga anak tunagrahita yang dijadikan sempel peneliti dalam mengambarkan pola perkembangan.

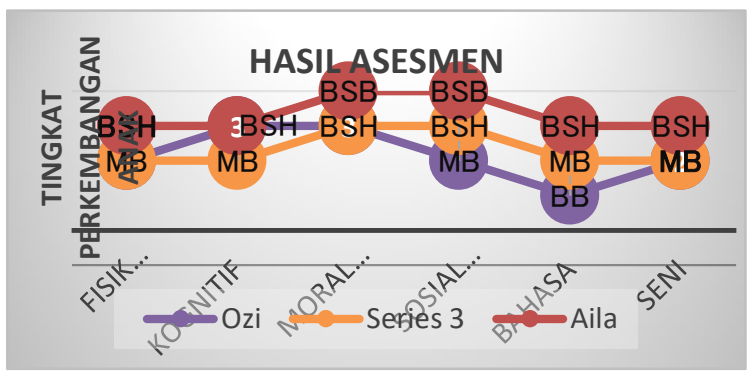

Tabel 5. Grafik Perkembangan Anak

Berdasarkan hasil observasi dan pengamatan pada hasil asesmen yang mengacu pada aspek perkembangan fisik motorik, kognitif, sosial emosional, nilai moral agama, seni dan bahasa, maka dapat diambil kesimpulan bahwa pola perkembangan anak tunagrahita selalu berpasang-pasangan antara aspek perkembangan. Untuk mudah dipahami makan peneliti mengambarkan pola perkembangan anak tunagrahita sebagai berikut:

\section{Pola Perkembangan Anak Tunagrahita}

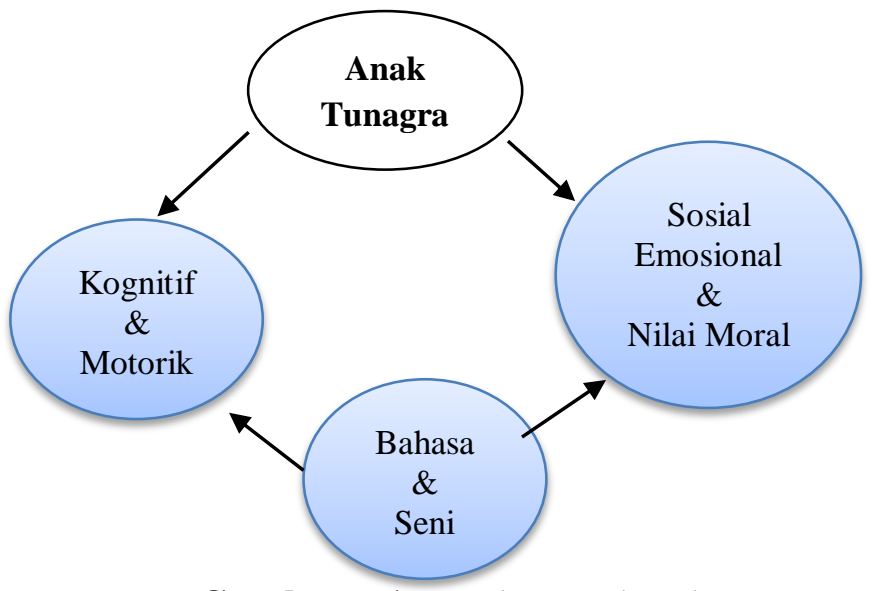

Gambar 1: Pola Perkembangan

Anak Tunagrahita
Mengacu pada hasil asesmen maka dapat disimpulkan bahwa pola perkembangan anak tuna grahita, selalu berkembang berpasang-pasangan antara satu aspek dengan aspek yang lain, aspek kognitif selalu berpasangan dengan aspek motorik, aspek sosial emosional berpasangan dengan moral agama sedangakan aspek perkembangan bahasa dan seni selalu mengiri aspek-asepk tersebut. Dari hasil asesmen penilaian, selain dapat mengambarkan pola perkembangan anak guru dapat memahami kekuatan dan kelemahan yang dialami anak dalam proses pembelajaran. Guru sebagai pendidik dapat memberikan informasi yang valid pada orang tua tentang kemajuan belajarnya sehingga orang tua dapat memperbaiki perilaku belajar anak pada waktu di rumah.

\section{Problematika Pelaksanaan Asesmen di TK LB C1 Dharma Rena Ring Putra I Yogyakarta}

Dalam pendidikan, kegiatan pembelajaran terutama dalam pelaksanaan asesmen tidaklah selalu berjalan dengan baik sesuai dengan harapan kita, hal tersebut dikarenakan ada beberapa faktor hambatan yang dapat mempengaruhi keberhasilan dalam proses pelaksanaan asesmen. Potensi hambatan dalam suatu institusi pendidikan sudah pasti ada, itu semua merupakan tantangan dan kelemahan yang harus dihadapi SLB C1 Dharma Rena Ring Putra I Yogyakarta. Sekecil apapun kekurangan atau kelemahan yang dimiliki akan berdampak terhadap pertumbuhan dan perkembangan anak. 
Berikut beberapa temuan peneliti mengenai faktor penghambat dalam proses pelaksanaan asesmen di SLB C1 Dharma Rena Ring Putra I Yogyakarta:

1. Belum terciptanya kerjasama yang baik dengan orang tua

Sebagian orang tua tingkat keperdulian terhadap anak sendiri rendah, hal ini mengakibatkan terhambatnya kerjasama yang akan dilakukan pihak sekolah dengan orang tua murid. Rendahnya keperdulian orang tua terhadap anak disebabkan karena paradima orang tua yang berangapan sekolah SLB seperti halnya bengkel tempat merawat dan memperbaiki anak berkebutuhan khusus jadi orang tua merasa tidak perlu ikut campur.

2. Tinggkat kemampuan anak yang berbeda-beda

SLB C 1 Dharma Rena Ring Putra I, merupakan sekolah yang menanggai anak tunagrahita. Sedangkan anak tunagrahita adalah anak yang memiliki tingkat kecerdasan dibawah rata-rata yang ditandai oleh keterbatasan intelegensi dan ketidak cakapan dalam berinteraksi. Selain itu anak tunagrahita dikenal dengan anak keterbelakangan mental.

Dari keterbatasan yang dimiliki anak membuat tingkat perkembangan dan pertumbuhan terhambat. Sehingga guru perlu membuat instrumen penilaian yang sesuai dengan tingkat kemampauan anak.

3. Belum adanya standar penilaian yang sesuai untuk anak tunagrahita.
Meski pada dasarnya acuan dan standar penilaian sudah ada pada permendikbud no 146 tahun 2014 serta permendikbud 137 tahun 2014, akan tetapi acuan dan standar penilaian tersebut tidak sesuai jika digunakan untuk anak tunagrahita. Hal ini didasari kemampuan serta perkembangan anak tunagrahita dibawah anak normal.

4. Minimalnya panduan buku penilaian pembelajaran

Salah satu penyebab ketidak adanya buku panduan penilaian di SLB C 1 Dharma Rena Ring Putra I, terutama untuk kelas TK dikarenakan tidak meratanya pendistribusian buku dari pusat. Selain itu SLB C C1 Dharma Rena Ring Putra I merupakan lembaga pendidikan yang berada di bawah yayasan swasta sehinga akses-akses dalam mendapatkan buku tidak mudah, sehingga guru mencari acuan penilaian secara mandiri.

5. Kondisi Lokasi Sekolah

Walaupun guru-guru di LB C C1 Dharma Rena Ring Putra I memiliki kompetensi yang baik dalam mengajar, akan tetapi beberapa guru di sekolah memiliki beberapa kendala salah satunya, jarak yang ditempuh antara kediaman guru dengan lokasi sekolah cukup jauh.

\section{SIMPULAN}

Pelaksanaan asesmen yang dilakukan guru dalam mengamati perkembangan anak di TK LB C 1 Drama Rena Ringputra I Yogyakarta dialkukan dengan dua cara yaitu: Pertama, Asesmen perkembangan 
anak disabilitas, pelaksanan dimulai dengan asesmen prasekolah yang bertujuan untuk mendiskripsikan kemampuan serta hambatan pada anak sebelum masuk sekolah, kemudia dilanjutkan asemen pasca sekolah, sebagai tindak lanjut sesmen pasca sekolah yang bertujuan mengembangkan dan memaksimalkan kemampuan anak dengan mengacu tahapan perkembangan anak disabilitas atau biasa yang disebut dengan TPPAD (Tingkat Pencapaian Perkembangan Anak Disabilitas). Kedua, Asesmen perkembangan anak tunagrahita dari sudut kenormal, pelaksanan asesmen anak disabilitas dari kenormal dimulai dengan pengamatan setiap hari, pencatatan harian, menganalisa data setiap bulan dan rekap perkembangan selama semester. Proses pelaksanan asesmen anak tunagrahita dari sudut kenormalanya mengacu pada STPPA (Setandar tingkat pencapaian perkembangan anak)

Berdasarkan hasil penelitian yang bersumber dari data asesmen guru, menunjukan pola perkembangan anak tunagrahita, selalu berkembang berpasangpasangan antara satu aspek dengan aspek yang lain, aspek kognitif selalu berpasangan dengan aspek motorik, aspek sosial emosional berpasangan dengan moral agama sedangkan aspek perkembangan bahasa dan seni selalu mengiringi aspekaspek tersebut. Dalam mengasesmen aspek-aspek tersebut tidaklah selalu berjalan dengan baik sesuai dengan harapan kita, hal tersebut dikarenakan ada beberapa faktor penghambat yang dihadapi guru dalam melaksanakan asesmen, dan beberapa kendala tersebut secara tidak langsung berdampak pada perkembangan anak, diantaranya: pertama, belum terciptanya komunikasi kerja sama yang baik antara orang tua dengan guru. Kedua, tingakat kemampuan dan keterbatasan anak yang berbeda-beda sehinga membuat guru kualahan dalam melaksanakan asesmen. Ketiga, belum adanya setandar penilaian yang sesuai dengan tingkat perkembangan anak tunagrahita. Keempat, minimalnya panduan buku penilaian pembelajaran yang disebabkan tidak meratanya pendistribusian buku dari pusat

\section{DAFTAR PUSTAKA}

Harun Rasyid, dkk, Asesmen Perkembangan Anak Usia Dini, Gama Media, Yogyakarta, 2012.

Lexy J. Moleong, Metodologi Penelitian Kualitatif, Bandung: PT. Remaja Rosdakarya, 2007.

Merisya Gabrina Tifali, "Meningkatkan Kemampuan Motorik Halus Melalui Media Papan Alur Pada Anak Cerebral Palsy Tipe Spastik”, Jurnal Ilmiyah Pendidikan Khusus, Universitas Negeri Padang, Vol 3 No 3, 2011.

Peraturan Menteri Pendidikan Dan Kebudayaan No 23, Tahun 2016, Pasal 4 dan Pasal 7.

Risky Setiawan, Pengembangan Asesmen Berfikir Kreatif Gunru Paud, Desertasi, Yogyakarta: Program Pascasarjanah UNY 2014. 
Muhammad Zainal Abidin. ANALISIS IMPLEMENTASI ASESMEN DALAM MENGAMATI PERKEMBANGAN ANAK TUNAGRAHITA DI TK SLB C 1 DHARMA RENA RING PUTRA I YOGYAKARTA. Early Childhood Vol. 2 No. 2a, November 2018

Sentot Kusairi, “Analisis Asesmen Formatif Fisika Sma Berbantuan Komputer" Jurnal Penelitian dan Evaluasi Pendidikan, Vol 16, Universitas Negeri Yogyakarta, 2012.

Sugiyono, Metode Penelitian Pendidikan: Pendekatan: Pendekatan Kuantitatif, Kualitatif, dan $R \&$ $D$, Bandung: Alfabeta, 2008.

Zuhairini, Filsafat Pendidikan Islam, Jakarta: Bumi Aksara, 1992. 